\title{
MOBILITY AND EARLY BRONZE AGE SOUTHERN AEGEAN METAL PRODUCTION
}

\author{
MYRTO GEORGAKOPOULOU
}

\subsection{INTRODUCTION}

Metal production in the southern Aegean dates back at least to the Final Neolithic (Coleman 1977, 3-4). Present evidence, however, suggests that during the ensuing Early Bronze Age (EBA: c. $3^{\text {rd }}$ millennium BC), production of copper, lead, and silver is attested in the Aegean on a large-scale - in the context of this period - for the first time, supplying the metal for the majority of artefacts consumed in the region (Gale and Stos-Gale 2002; Stos-Gale and Gale 2003). Interestingly, for copper at least, this local production largely ceases in the following Bronze Age periods, a phenomenon supported both through lead isotope analysis and through archaeometallurgical fieldwork. This paucity of copper production is presently attributed to the limited scale of relevant southern Aegean, particularly Cycladic, mineralisations and their possible exhaustion at the end of the third millennium BC, coupled with availability of metal from elsewhere (Bassiakos and Tselios 2012).

Academic interest in EBA Aegean metal production has largely shifted in the last fifteen years from provenance-oriented studies, with the widespread application of lead isotope analysis in this region during the 1980s and 1990s (see overviews and references in Gale and Stos-Gale 2002; Stos-Gale and Gale 2003), to a surge of smallscale, site or region-specific archaeometallurgical studies (see examples in Betancourt 2006; Day and Doonan 2007; Georgakopoulou et al. 2011). The aim of the latter is to understand the nature and technology of metallurgical activities undertaken in a particular context.

The present paper relies on the data available so far to examine, first, how mobility is manifested within the first stages of metal production. Second, it considers technological variability and homogeneity in metal production sites, concentrating primarily on furnace shape and operation. Through this analysis the paper explores how mobile the technology of smelting was in the context of EBA Aegean metal production and considers what the emerging patterns potentially show about interaction and knowledge transfer among the people involved in these activities.

\subsection{METAL PRODUCTION AND METALWORKING}

Production of a metallic artefact involves a series of processes from mining of the ore to the final shaping of the artefact. The simplified diagram in Figure 4.1 presents the main steps of the whole process, common to all metals produced in prehistory from their respective ores (i.e. excluding gold or other native metals). These can be divided into two groups: the first involves production of the raw metal and the second its working, with various steps included in the latter such as melting, refining, hot and cold-working. When comparing the two, various differences emerge with important implications: 
- Extent of transformation of starting materials: Looking at the pyrotechnological stages within them, the process of smelting involves a dramatic physical transformation of matter, starting with what in many cases is a colourful stone (e.g. the green copper ore malachite) and ending with a drastically different material, reddish, shiny, and ductile copper metal. In melting, on the contrary, solid metal is liquefied and re-emerges as metallic matter again upon cooling, only in a different form.

- Locality associations of the starting materials: Another difference relates to locality associations of the starting materials in each case. The stages outlined in Figure 4.1 are inversely bound by geographical limitations. Mining, by definition, has to take place at the sources, with the remaining stages showing less and less attachment to the original source. Final shaping of the artefact can of course be completely detached from the location of its parent ore, particularly as many cycles of recycling may intervene.

- Variation in the properties of the starting materials: In smelting the nature of the starting materials can differ significantly. Taking copper as an example, whether produced in the Aegean, Jordan, Cyprus, or the Alps, the properties of the metal used during the metalworking stages will be largely the same, assuming of course it is unalloyed. The miner on the other hand is not only confronted with a very different setting (Hardesty 2003), but also, depending on the geology of the particular area, had to deal with secondary green and blue ores or the golden sulphide chalcopyrite that not only look very different, but subsequently require different processing in order to produce the same copper metal. This ore may in turn be found in a siliceous matrix, ferrous or non-ferrous-rich, or an entirely different calcareous matrix all reacting differently in the furnace. Furthermore, the nature of the fuel as well as the clays used for furnaces and the other necessary ceramics need to be taken into account, although these may vary within both metal production and metalworking processes.

- Visibility of technological choices: While production of raw metal, from mining to smelting, is, to a large extent, bound by the geological and geographical environment, within every stage of the production sequence there is room for choice. The archaeometallurgical record portrays numerous examples of how people did things differently (Childs and Killick 1993; Craddock 2001; Ottaway 2001). Here is, however, another distinction between the metal production and metalworking stages. Choices made in the latter will, to some extent at least, be seen and felt by the consumer, whether in the shape of the artefact or differences in physical properties induced by alloying or different metalworking treatments. On the contrary, neither the consumer, nor even the metalworker, have any way of knowing, unless they were present themselves during production, whether the raw metal used was made from an oxidic or sulphidic ore, whether a flux was used during smelting, or whether arsenic was added during or after smelting. These choices, situated within the metal production stages, are invisible in the final artefact, and therefore in principle unknown to the people not present during smelting (Gosselain 2000).

Some of the points raised here apply to some degree to ceramics and glass, the other two main pyrotechnological products of antiquity. In the case of ceramics, choices made in the early stages of production before shaping can often be reconstructed archaeologically through the study of the ceramic fabric on the products themselves (e.g. Kiriatzi 2003; Kiriatzi et al. 2011). With metals, although these choices are 
practically invisible in the final product, the ample archaeometallurgical debris or features left behind by each of the metal production stages provide a wealth of relevant information.

The distinctions highlighted above justify the choice of the author to explore some of the issues raised in this volume focusing specifically on the primary metal production stages, from mining to production of raw metal. The paper provides a first, preliminary approach to the relationship between mobility and metallurgy, while it is acknowledged that a fuller discussion of this subject should develop to include the entire production sequence and subsequent consumption patterns.

\subsection{EBA SOUTHERN AEGEAN METAL PRODUCTION: AN INHERENTLY MOBILE CHAÎNE OPÉRATOIRE}

\subsubsection{Distribution of ore sources exploited in the EBA southern Aegean}

There are several copper and lead-silver ore sources in the south-central Aegean, but those of south-eastern Attica and the western Cycladic islands presently appear to have been more prominent in terms of EBA exploitation (Gale and Stos-Gale 2002). Their importance stems, on the one hand, from indirect evidence, that is the attribution of provenance of numerous metallic artefacts of this period to sources in this region through lead isotope analysis (Gale and Stos-Gale 2002; Stos-Gale and Gale 2003 and references within), and, on the other hand, from direct evidence provided by several local mining and smelting sites that will be discussed further below.

South-eastern Attica hosts the large multi-metallic ore deposit of Lavrion, which is proposed by lead isotope analysis to be a source for lead, silver, and copper in this period (Spitaels 1984; Gale and Stos-Gale 2002; Gale et al. 2008). Unfortunately, mainly due to later large-scale exploitation in the Classical and particularly the early modern periods (Conophagos 1980; Kakavogiannis 2005), very little direct evidence for prehistoric exploitation survives (Spitaels 1984; Mountjoy 1995) and no smelting sites are known so far. Although the importance of Lavrion as a source for silver in the EBA is acknowledged from a wealth of other finds in the broader region (Kakavogianni et al. 2006; Kakavogianni et al. 2008), the evidence for copper production is presently less clear.

In the Cyclades, however, the picture is different to Lavrion and far more complicated. The islands are known for their abundance of small-scale, dispersed mineralisations that are usually of no modern economic significance, at least not for non-ferrous metals (Gale and Stos-Gale 2008; Bassiakos and Tselios 2012 and references within). Some of the silver-rich lead deposits, such as Ayios Sostis on Siphnos (Wagner and Weisgeber 1985), were substantial and there is evidence that these were exploited also in later historic times. Conclusive evidence for third millennium BC mining for silver-rich lead ore has been identified at Ayios Sostis, and probably also other sites on Siphnos (Wagner and Weisgeber 1985). For other Cycladic islands with lead ore deposits there is presently no direct evidence that these were exploited in the EBA. 
Copper minerals are also reported on a number of islands, usually as minor accessories to iron ore deposits (Gale and Stos-Gale 2008; Bassiakos and Tselios 2012 and references within). The presently attested scarcity of copper minerals in the Cyclades, however, is in stark contrast with the extensive evidence for local production of copper in this period. Ancient and possibly also modern, primarily iron, mining have undoubtedly contributed to this picture. Presently, the only evidence for copper mining known from the Cyclades comes from Kythnos at Cape Tzoulis, Aspra Kellia, and Petra, with all three indicating open-air mining (Bassiakos and Philaniotou 2007; Gale et al. 1985; Hadjianastasiou 1998; Hadjianastasiou and MacGillivray 1988).

\subsubsection{Distribution of EBA Aegean smelting sites}

Turning to smelting, at least thirteen sites with evidence for EBA copper smelting ${ }^{1}$ and two with evidence for EBA lead smelting ${ }^{2}$ have been identified so far in the southern Aegean (Figure 4.2), ${ }^{3}$ with the majority concentrated in the western Cyclades. A few of them have been excavated (Hadjianastasiou and MacGillivray 1988; Betancourt 2006; Papadatos 2007; Papadopoulou 2011), to different degrees, while the remaining have been dated to the EBA by surface pottery and thermoluminescence dating of furnace fragments (Zacharias et al. 2006a; 2006b), and more rarely by radiocarbon (Stos-Gale 1989).

These sites differ significantly in terms of three parameters outlined below (See also Catapotis 2007).

1. Scale: By far the largest known copper slag heap in the area is that of Avessalos on Seriphos with estimates for 100,000 tons of slag present. Still, although there is evidence that part of this material is dated to the EBA, the majority appears to be later and hence an estimate of the EBA scale is not possible (Gale et al. 1985; Philaniotou et al. 2011). Beyond Avessalos, Skouries on Kythnos and Kephala on Seriphos stand out as the largest, with rough estimates suggesting several hundred tons of slag (Catapotis 2007; Gale et al. 1985; Philaniotou et al. 2011). Medium-sized slag heaps ranging one to a few tens of tons are Phournoi (Seriphos), Chrysokamino (Crete), and Ayios Sostis (Siphnos), while the remaining sites represented on Figure 4.2 would be estimated to

\footnotetext{
${ }^{1}$ These are Raphina, Sideri, Paliopyrgos-Aspra Spitia, Pounta, Lefkes, Avessalos, Kephala (Seriphos), Phournoi, Skali (location nearby settlement of Akrotiraki on Siphnos, scale of map does not allow separate representation), Dhaskalio-Kavos, Chrysokamino, and Kephala-Petras. Note that Kephala (Kea) is not included in this count, as it is of Final Neolithic date.

${ }^{2}$ Ayios Sostis and Kasela on Siphnos (as for Skali, the location of Kasela is near Akrotiraki settlement on Siphnos, not possible to depict separately due to scale of map).

${ }^{3}$ There are some discrepancies with the recent synthesis of EBA copper smelting sites presented by Catapotis 2007. Only clearly identified sites, all visited by the author or published adequately are presented here. The copper slag scatter at A. Symeon on Kea cannot presently be dated (Caskey et al. 1988). The location of Petalloura and Aerata are uncertain from the published reports and they may refer to the site of Skali (Siphnos) and the settlement of Plakalona (Seriphos) respectively. There is only a brief report of A. Ioannis Eleimon and A. Ioannis Theologos and no further study has been undertaken (Bassiakos and Philaniotou 2007, 36). The nature of the furnace identified at Kolonna on Aegina is unclear and no smelting slags have been identified so far (Gauss 2010, 741; Walter and Felten 1981, 23-28). Finally, the analyses of the few undated slags identified at Konakia on Keros were inconclusive as to whether these were related to copper or iron metallurgy (Bassiakos and Doumas 1998) and the latter is more likely based on recent results from material collected during intensive surface survey (Georgakopoulou in press). For these reasons the above sites are not considered here, without suggesting that they are not in fact associated with EBA copper smelting, while the site of Skali on Siphnos has been identified since.
} 
less than one ton of slag, ${ }^{4}$ with only a few fragments found on some sites like Kephala Petras on Crete (Catapotis et al. 2011; Papadatos 2007) and Lefkes and Pounta on Kythnos (Bassiakos and Philaniotou 2007).

2. Proximity of smelting to possible ore sources: Several different patterns are noted. The lead smelting site of Ayios Sostis on Siphnos is located beside the mine (Wagner and Weisgerber 1985). Similarly, mineralisations with convincing indications for exploitation, were identified at Aspra Kellia and Petra at a short distance of less than $1 \mathrm{~km}$ from the copper smelting sites of Paliopyrgos-Aspra Spitia and Sideri on Kythnos (Bassiakos and Philaniotou 2007). For these three sites therefore it is clear that smelting was taking place in the immediate vicinity almost adjacent to the mine. In the case of the two small smelting sites of Skali and Kasela on Siphnos, for copper and lead respectively, corresponding sources are not known in their immediate vicinity. At the opposite side of the Platy Gialos bay, however, at Aspros Pyrgos (c. $2 \mathrm{~km}$ overland from Skali) (Wagner and Weisgerber 1985, 176-178; Gale and Stos-Gale 2008), there is a substantial copper mineralisation, while lead ores are abundantly present on Siphnos. Although there are presently no conclusive geochemical data, it is most likely that the sources of ores used at Skali and Kasela were local.

The large copper slag heap of Skouries is located relatively close to the mine of Cape Tzoulis (c. $2 \mathrm{~km}$ south of Skouries), although doubts have been expressed as to whether this was a source for the Skouries smelting, given the steep climb required to access the smelting site from Tzoulis (Hadjianastasiou 1998). Another two small copper mineralisations were also identified near Skouries (at c. $400 \mathrm{~m}$ and $700 \mathrm{~m}$ respectively) (Bassiakos and Philaniotou 2007, 25). Still, these occurrences appear presently surprisingly small when considered against the extent of this slag heap. The much broader lead isotope field occupied by the Skouries slags compared to the analysed Kythnian copper ores has led to suggestions that Skouries formed a central smelting site, where ores were brought from different islands (Stos-Gale 1998; 2000; Kayafa et al. 2000; Gale and Stos-Gale 2008). While there are reasons to contest the ability of the current lead isotope database to reach such conclusions (Georgakopoulou in press (a)), the scarcity of surrounding ores versus the quantity of the slags make this a very possible scenario. Indeed this kind of inter-island transfer is particularly plausible if we consider the proximity of the Cycladic islands between them (Figure 4.3) ( $^{5}$ and the prominence of short-distance maritime travel in this period (Broodbank 2000; Broodbank this volume). A similar situation may be envisaged for the sites of Kephala and Phournoi on Seriphos. The two sites, situated in the north/ northwest schist units of the island, are at a significant distance from the island's rich secondary iron ores in the southwest marble zones (c. $10 \mathrm{~km}$ direct distance overland from Phournoi to Mega Livadi mines and about the same for coastal maritime distance) and the magnetite deposits in the central part of the island at the contact of the schist and granodiorite units (c. 5km direct overland distance) (Georgakopoulou et al. 2011; Philaniotou et al. 2011). Both of these rich iron ore deposits, which were extensively mined in the modern period, bear copper minerals, today only in trace quantities. Although a faint copper mineralisation was recognized close to the Kephala slag heap, no indications of ore

\footnotetext{
${ }^{4}$ Note that there is no data on the size of the Raphina workshop

${ }^{5}$ Distances between neighbouring coasts of adjacent western Cycladic islands are c. $15 \mathrm{~km}$, easily within a day's reach with an Early Cycladic small canoe, and even more so with a Cycladic longboat (for relevant data see Broodbank 2000, 102).
} 
exploitation nor evidence for a substantial deposit were found. Unless large sources nearby remain unidentified, the most likely hypothesis is that ores were brought from sources elsewhere on Seriphos and beyond for smelting at Kephala and Phournoi. Thus, at least in the case of Kephala and Skouries, the original choice for using these locations for smelting may have been partly based on the presence of small-scale mineralisations, exhausted relatively quickly. Subsequently, however, it is likely that these sites were used for repeated smelting activities with ores brought in from different locations (see also below). In short, returning to the question of ore source and smelting proximity, in the case of the western Cycladic smelting sites in general and for Raphina on Attica, one can consider that even if not adjacent to an ore source, they are located within a broadly metal-rich zone, where short-distance (involving less than a day of one-way travel) ore transportation was taking place, although different patterns of spatial relations emerge.

Further smelting sites are, however, known outside this 'metal-rich' region, specifically at Chrysokamino and Kephala Petras on Crete and Kavos Promontory on Keros. Although Crete does have limited copper mineralisations, lead isotope analysis suggests that the ores smelted at Chrysokamino are not Cretan and were brought from outside the island, most probably from the western Cyclades (Stos-Gale and Gale 2006). It should be noted, however, that comparisons of slags and ores from Chrysokamino have suggested that mixing of minerals was taking place, a practice that could have influenced attribution to specific sources (Bassiakos and Catapotis 2006, 346). Keros on the other hand is largely devoid of metal sources and the variable chemical composition of the slags again suggests importation of ores from outside the island (Georgakopoulou 2007a; in press (b)). For Chrysokamino and Keros, therefore, transportation of ores from longer distances was taking place (involving several days of one-way travel).

3. Proximity of smelting sites to contemporaneous settlements: Most of the smaller smelting sites are directly associated with a settlement. Skali and Kasela are located less than 500 m west and south of Akrotiraki respectively (Figure 4.4) (Papadopoulou $2011 ; 2013$ ) and similarly close are Kavos Promontory to the settlement on Dhaskalio (Georgakopoulou 2007a) and the Raphina workshop to the homonymous settlement excavated at the same time by Theocharis (Theocharis 1952: Fig. 1). All of these sites appear to be directly associated with these settlements, located just outside of the habitation areas themselves, possibly to keep away the polluting metallurgical activities and / or to add a mystical element of isolation to the activities. In the case of Chrysokamino, there is no association with one specific large settlement, but there are habitation sites in the region, with a pattern of farmhouse clusters developing during EMIII. It is proposed that the inhabitants of such clusters may have been involved in the metallurgical activities of Chrysokamino (Betancourt 2006b; 2006c; Haggis 2006). Overall, it is becoming more evident that small-scale metal production in the vicinity of some of the EBA settlements was not uncommon (Georgakopoulou 2007b). The question now raised, however, is how widespread this phenomenon was and which types of settlements were involved in such activities in each case.

Contrary to the smaller smelting sites, none of the large smelting sites of the western Cyclades (Skouries on Kythnos; Kephala and Phournoi on Seriphos; Ayios Sostis on 
Siphnos) appear to be near a contemporaneous settlement and the same is true for the smaller sites of Paliopyrgos-Aspra Spitia, Sideri, and Pounta on northern Kythnos.

\subsubsection{Chronology of EBA Aegean smelting sites}

The above discussion suggests significant variability in the spatial organization of metal production activities in the southern Aegean that presently includes large and small smelting sites in isolation from settlements within the metal-rich zone (patterns A and B, Table 4.1); small-scale smelting within the same region associated with a specific settlement (pattern C, Table 4.1); and, on the other hand, at a distance from any ore sources, smelting in the proximity of a settlement or habitation clusters (pattern D, Table 4.1). These differences cannot be attributed to chronological development, but they can be shown to largely co-exist. On the basis of recovered pottery, the Raphina workshop dates to the early EBII period (Korakou culture), while the nearby settlement shows both this phase and a subsequent late EBII Kastri/Lefkandi I phase (Theocharis 1951; 1952; Douni pers. comm.). A preliminary study of the pottery from Akrotiraki has suggested that it was occupied consecutively from the Final Neolithic to the late EBII Kastri phase. It cannot be presently concluded during which phases within this long period metallurgy was practiced, as the few sherds recovered from Skali and Kasela could only be characterized broadly as Early Cycladic (Papadopoulou 2011; 2013). The settlement of Dhaskalio, off Keros, shows three chronological phases, with habitation starting from the beginning of the EBII (Renfrew et al. 2012). Again, it is unclear to which phase(s) the smelting workshop corresponds, but remains associated with secondary metalworking activities were recovered from all three phases at Dhaskalio (Georgakopoulou in prep.). Finally, on Crete the few slags and ores from Kephala Petras are amongst the earliest evidence for metal production in the southern Aegean dating to between the FN-EMI periods (Papadatos 2007, 161-2). Pottery from all phases between FN-EMIII was recovered during excavations at Chrysokamino, with the middle phases, however, being significantly under-represented (Betancourt 2006). The excavators proposed that the site was in operation at different times throughout the EBA, although it is acknowledged that the EMIII would have been the main phase of use (Muhly 2004), while the association of the few earlier pottery fragments recovered with metallurgy is challenged (Catapotis et al. 2011, 75; Papadatos 2007, 155).

In the case of the large smelting sites of Kythnos (Skouries) and Seriphos (Kephala, Phournoi, and Avessalos) dating to particular phases is even more difficult, as none have been stratigraphically excavated. Furthermore, due to their size, it is very plausible that the sites were in use over several generations and across established chronological subdivisions. Sideri, Kephala, and Phournoi have been dated with thermoluminescence dating of surface furnace fragments, with the resulting dates associated with large errors and covering almost the whole of the third millennium BC (Zacharias 2006a; 2006b). Similarly for Skouries, although the diagnostic pottery recovered from the site was dated solely to the EBII (Hadjianastasiou and MacGillivray 1988), claims about this being a single period site cannot be confirmed in the absence of excavation.

Despite the enduring problems with the chronological resolution of most of the presently known EBA southern Aegean smelting sites, it is clear that the differences identified above in their spatial organization cannot be attributed to chronological evolution as suggested for example in Chalcolithic-EBA Feinan where small-scale settlement-based smelting at a distance from mines is succeeded by large-scale smelting 
in the vicinity of the mines (Weisgerber 2003). During the middle of the third millennium BC, in the EBII at least, several different spatial patterns appeared to coexist in the southern Aegean. Furthermore, the predominantly island environment of the region under consideration adds a different dimension to considerations of proximity, not encountered in other prehistoric metal-producing regions.

\subsubsection{Mobility in EBA Aegean metal production}

Although the majority of evidence for smelting is still largely concentrated in the western Cycladic islands, a picture that is unlikely to change in the future, the new data highlight more complex spatial patterns than could be suspected prior to the last decade (Broodbank 2000, 292-297). Various forms of mobility, of people, raw materials, as well as final products, form an integral part of metal production activities. Mobility here is of a small to medium range, within a relatively confined region, but periodic and probably also seasonal (Broodbank 2000, 92-6) with a strong emphasis on maritime travel.

But who is moving and how? How widespread was involvement in metal production activities among the EBA communities of the southern Aegean and what scale of mobility did it involve (Chapter 1 this volume)? In his synthesis of the EBA Cyclades, Broodbank (Broodbank 2000, 292-298) suggested that metal procurement was based on a combination of direct access to ore mining and smelting by certain communities or groups, living within or outside the 'metal-rich region', together with indirect acquisition of ores, raw metal, or ready-made artefacts by others. Broodbank, acknowledged that there is no evidence for direct control of ore sources in the EBA Aegean, but suggested that control of metal production would have been indirect, based on resources (human and material) for maritime travel (as far as access to the western Cyclades is concerned) and metallurgical knowledge.

Significant new evidence has come forward in the last decade, but still the model appears to largely hold. The dispersed spatial distribution of smelting sites and the absence of settlements near the larger smelting sites or the prehistoric mines of the western Cyclades, still suggests a lack of direct control of resources by any one settlement or social group within the metal production industry of the EBA Aegean. Metal production attached to specific settlements, is now attested, but appears to have been generally of a small scale, as discussed above. New evidence has also been acquired from settlements within the metal-rich zone of the western Cyclades; Plakalona (Pantou in press) on Seriphos and Akrotiraki (Papadopoulou 2011; 2013) on Siphnos have both brought forward evidence for metallurgical activities, although unfortunately both are at an early stage of their study. Plakalona, specifically, is located within the rich secondary copper-bearing iron ore deposits of southwestern Seriphos, while the copper sources of Aspros Pyrgos are at a short distance from Akrotiraki. Although it is evident that these two settlements were involved in ore procurement and metal production activities, there is no reason to suggest that they had any limiting control over all or even their immediate resources (Broodbank 2000, 294). Even, if they did control access to their immediate resources, however, a point that remains to be clarified, different set-ups may have been at play for different sources, a diversity already argued in the case of the Yali and Melian obsidian exploitation (Georgiadis 2008). Furthermore, the significant distance of Plakalona and Akrotiraki from the large smelting sites of Seriphos (Kephala and Phournoi) and Siphnos (Agios Sostis) 
respectively, makes it unlikely that their inhabitants controlled the corresponding metallurgical activities and it is even unclear whether they were involved in them at all.

The evidence with regards to mobility discussed so far concerns primarily copper. Lead/ silver production appears presently to have been far more spatially restricted. Despite the wider distribution of lead ores in the Cyclades (Gale and Stos-Gale 1981), only the sources at Lavrion and Siphnos appear to have been exploited during the EBA, based on both lead isotope results and direct archaeometallurgical finds. Lead smelting sites are presently known only on Siphnos (Papadopoulou 2011; Wagner and Weisgerber 1985), while production should also have taken place in the Lavrion area, although relevant evidence are unsurprisingly lacking. The following step in the production of silver from argentiferous lead, that of cupellation, appears to have been more widely distributed, with litharge presently identified at several EBA settlements (Wilson 1999, 144-147; Georgakopoulou 2007a; Kakavogianni et al. 2008).

\subsection{TECHNOLOGICAL TRADITIONS IN EBA SOUTHERN AEGEAN SMELTING}

Turning to the technological evidence for metal production in the EBA southern Aegean, the focus here is on smelting, as the data for mining is very limited. A couple of underlying common characteristics are noted. First, the majority, if not all, of the sites are located on north-facing windswept promontories, a choice which suggests the exploitation of the natural draughts for the operation of the furnaces. Second, the absence of visible charcoal remains is a notorious problem on these sites, impeding both the application of radiocarbon dating and archaeobotanical studies for the identification of the tree species used.

The evidence for the technology of smelting, is however, far from uniform. The most telling parameter concerns the shape and operation of the furnaces, which are the focus of this section. Furnace remains are usually identified on metallurgical sites as scattered slagged ceramic fragments, as furnaces were frequently destroyed after the smelt, leaving little behind on which to base a reconstruction. A particular idiosyncrasy of some EBA Aegean furnaces is the presence of multiple perforations on the wall fragments (Table 4.1). Outside the Aegean, the only reports of similar perforated structures used in metallurgy come from entirely unconnected much later contexts in Thailand (Pryce et al. 2013) $)^{6}$ and the Bolivian Andes (Cohen et al. 2009). In the EBA Aegean clear use of furnaces with perforated walls is attested on the sites of Chrysokamino on Crete (Betancourt 2006a) and the two adjacent sites of Sideri and Paliopyrgos-Aspra Spitia on Kythnos (Bassiakos and Philaniotou 2007), where the vast majority of broken wall fragments bear evidence for multiple perforations. On Seriphos only a few of the ceramic wall fragments at Kephala (Philaniotou et al. 2011) ${ }^{7}$ had evidence for perforations, while the majority did not. Furthermore, only one perforation was usually seen per fragment, although a couple of fragments showed more. Interestingly, Theocharis $(1952,131)$ mentions the presence of perforations on the furnace walls from Raphina, although unfortunately the material is neither illustrated

\footnotetext{
${ }^{6}$ Note that recent re-assessment of these structures suggests they were not associated with copper smelting activities (Pryce et al. 2013, 249)

${ }^{7}$ A similar pattern is seen also at the site of Avessalos on Seriphos, although dating of this site is complex and for this, it is not included in this discussion.
} 
nor has it been studied since, so no further information is available. Perforations are also reported and illustrated on the few metallurgical ceramic finds from the Final Neolithic site of Kephala on Kea (Coleman 1977, 4). All of the above sites are associated with copper smelting, however, more recently perforated furnace wall fragments were also found at the lead smelting site of Kasela on Siphnos (Papadopoulou 2013). On much smaller scale, similarities in the concept are noted between these furnaces and the perforated clay utensil, known from Heraion on Samos, interpreted as a brazier, and proposed by Doumas as a possible Bunsen burner for working precious metals (Doumas 2011, 176-77 and Figs. 17.24, 17.25).

Despite their widespread distribution across the southern EBA Aegean, perforated furnaces are not present in all metallurgical sites of this period (Table 4.1). There is currently no evidence for their presence at Skouries on Kythnos or Phournoi on Seriphos, although both sites have numerous large furnace wall fragments visible on their surface. Similarly, they were not found at Dhaskalio Kavos on Keros, Ayios Sostis and Skali on Siphnos, Pounta and Lefkes on Kythnos or among the few metallurgical finds of Kephala-Petras on Crete, although in all of the latter sites metallurgical ceramics tend to be very fragmented.

Even among the sites where these fragments are found, however, several differences are noted (Table 4.2). Unfortunately there are presently no data for comparison from the earlier excavations of Kephala on Kea and Raphina on Attica, so these sites cannot be included in the following discussion. Among the remaining ones, as mentioned earlier, perforated furnace fragments represent only a minor percentage at Kephala and Avessalos on Seriphos and only one hole is usually retained on each fragment, making it unclear if these are actually fragments of truly perforated walls, like elsewhere, and if so how common their use was on this site. The finds from Kasela also stand out as they are the only ones associated with lead smelting, while surprisingly there were no indications for perforations on the metallurgical ceramic fragments from the nearby copper smelting site of Skali. It should be noted that both sites appear to be directly associated with the settlement of Akrotiraki, as both copper and lead slags were recovered during excavations on the settlement itself.

Even looking at the clearest examples, however, those of Sideri and PaliopyrgosAspra Spitia on Kythnos and Chrysokamino on Crete, Bassiakos and Philaniotou (Bassiakos and Philaniotou 2007, Table 2.11) have noted significant differences. On both, the perforated fragments are reconstructed as parts of chimneys placed on top of a small shallow bowl. The perforations would allow air to come into the furnace promoting combustion. Differences are noted both in the thickness of the fragments, with the Chrysokamino ones being systematically significantly thinner, and in the direction of the holes, which in the Kythnian examples are directed downwards, while at Chrysokamino they are directed horizontally. The Kythnian examples show strong similarities with the other Cycladic examples, except that on Seriphos, as discussed before, multiple perforations on the same fragment are rare. A further telling difference, however, is the evidence for the use of bellows, which is to date unique to Chrysokamino. Admittedly this is the only site, where large-scale excavation has been undertaken. On the other hand, both at Paliopyrgos-Aspra Spitia and at Akrotiraki on Siphnos, near Kasela, blowpipe tips have been found. The one from Akrotiraki exactly fits into the holes of perforated fragments from nearby Kasela (Papadopoulou 2013, 44, 
Figure 9b). On the basis of the above, a different operation of the perforated furnaces is suggested in the two cases. Aside from natural draught entering the furnace through the perforations, bellows would be furthermore used at Chrysokamino to provide more air at the base of the perforated shaft, while on the Kythnos and Siphnos examples air would be blown using blowing pipes through the holes into the furnace (Bassiakos and Philaniotou 2007, 46-7). The function of the holes in the two cases therefore would be somewhat different.

Lastly, there is some evidence in the Cyclades for completely different structures associated with smelting furnace use. First, at Skouries on Kythnos, where there are no perforated furnaces, round, stone-lined structures of c. $4 \mathrm{~m}$ in diameter are still visible on the surface at the top of the slope occupied by the slag heap. These are thought to surround much smaller furnace bases, as one such base was identified within one of them during small-scale excavation (Hadjianastasiou and MacGillivray 1988). Catapotis proposes that such a setting may have been used to demarcate the work spaces of different groups operating in the same area (Catapotis 2007). Similar structures are not known in any of the other sites discussed here. Finally, at Kephala on Seriphos two furnaces carved on the schist bedrock were identified (Philaniotou et al. 2011, Fig. 16.3); again similar structures are not presently known elsewhere in the Aegean.

The widespread distribution of perforated furnace fragments within the Aegean has led to its characterization as an 'Aegean metallurgical tradition' (Pryce et al. 2007, 5534). Even though the differences are acknowledged, the concept of perforations in smelting furnaces is thought to have been around for 1000 years (Catapotis et al. 2008, 114). The present absence of similar evidence from elsewhere suggests that this is indeed an Aegean tradition, but what should also be emphasized is that, as the above discussion demonstrates, there is by no means a single Aegean tradition in the shape and operation of smelting furnaces, and that in fact variability is more the norm than the exception. Equally interesting is of course the noted variability within this technological tradition.

The question is no doubt raised; were these different technologies synchronous or do they represent a technological development through time? There are no doubt serious limitations here, as lack of stratigraphy in excavated metallurgical sites, or in many cases absence of excavation altogether, prohibit a clear chronological resolution. Still, these different technologies can be shown to have largely co-existed. The earliest evidence for perforated metallurgical ceramics comes from few fragments from Final Neolithic Kephala on Kea (Coleman 1977, 3-4). Unfortunately, it is not clear, based on the published evidence, whether these are indeed furnace fragments and the actual finds cannot be examined anymore. If, however, this is indeed the earliest appearance of this practice, and given that the latest is associated with Chrysokamino, dated primarily, if not solely, to Early Minoan III, with sites such as Raphina and Akrotiraki dating in the middle of the EBA (Table 4.2), then indeed the concept of the perforated furnaces was present for the entire span of the third millennium BC (Catapotis et al. 2008, 114), although practiced somewhat differently in different sites, while on others within this period, altogether absent. Part of this diversity would be temporal, as is clear, for example, with the use of bellows at Chrysokamino dated to the end of the EBA (Early Minoan III-Middle Minoan IA) (Betancourt 2006, 126), but overall it undoubtedly 
emerges that at the peak of local Aegean metal production, around the middle of the EBA, different ways of smelting co-existed.

\subsection{DISCUSSION}

On the basis of spatial evidence in the south-central Aegean and accepting a model of largely free access to resources as discussed above, several scenarios can be considered, with many or all of these possibly happening simultaneously. Communities from within the 'metal-rich' zones may have sent expeditions to mine ore from nearby sources, bringing these back to the settlements for smelting (e.g. Akrotiraki) or taking them to larger smelting sites used over generations (e.g. Skouries); this same ore collected from local communities may have been exchanged and shipped elsewhere for smelting; or groups may have travelled to the sources from outside this 'metal-rich' zone, prospecting for ore, mining, and then smelting nearby or, alternatively, transporting this ore for smelting at home or exchanging it with other communities. In short, different groups, by no means all coming from the Cyclades (Broodbank 2000, 198), must be envisaged to move within the same physical landscape for the same purpose: to make metal. It is also clear that some of the craftspeople must have been directly involved in these travels as mining and smelting are seen to take place away from settlements. In this case stays in one particular place would have lasted a few days, while mining of ore and smelting were undertaken.

The technological evidence discussed above suggests that although different groups were exploiting the same, relatively restricted physical landscape, different smelting practices were employed. On the other hand, the distribution of perforated furnace fragments suggests sharing and transmission of knowledge across sites, as well as differential adoption and appropriation of technological elements. Interestingly, the presence of perforated furnace fragments appears to geographically traverse our present understanding of Cycladic, Minoan, and Helladic EBA, while the western Cycladic islands, presently by far the richest in archaeometallurgical evidence, host a variety of different smelting practices.

How is this picture to be explained? Are the different technological practices the result of adapting to different physical and environmental parameters at different sites? There is presently no such consistent evidence. Even though there are differences in the compositions of slags between sites ${ }^{8}$ these do not correlate with the use of different types of furnaces, while the landscape features of most of these sites are remarkably similar, as discussed before. In fact, experimental reconstructions of perforated and non-perforated shaft furnaces have shown the advantages of the use of perforated furnaces, achieving higher temperatures as well as allowing for a more attractive visual display among the participants (Pryce et al. 2007). If the technology was around then, why was it not adopted on all sites? And, on the other hand, as smelting is a confined technological practice, known primarily to its practitioners and frequently undertaken in isolation from community members not involved (Childs and Killick 1993, 325), how was technological knowledge transmitted between those sites, where it appears to

\footnotetext{
${ }^{8}$ e.g. Chrysokamino slags (Bassiakos and Catapotis 2006) have significantly different composition to those from Kythnos (Bassiakos and Philaniotou 2007) and Seriphos (Georgakopoulou et al. 2011).
} 
be shared to some extent? Was knowledge shared but in some cases different practices deliberately maintained to re-enforce group identities? Or was it restricted, only witnessed by the practitioners themselves and only transferred through limited social avenues? What, in short can we infer, about interaction between the different groups producing metal in this region?

To this end some thoughts with regards to the particularities of the processes discussed here can be offered at this stage. Groups reaching the sources from outside the 'metal-rich' zone would have to undertake significant prospection to find suitable ores and the other necessary raw materials (clays, charcoal, etc.) in a less familiar landscape. Compared to obsidian, the much more dispersed distribution of ore sources, particularly in the western Cyclades, certainly posed different challenges. As discussed at the start of this paper, the nature of the raw materials may have differed from place to place. Indeed within the geology of Seriphos, for example, three distinct metalbearing units are noted, composed primarily of hematite/ limonite (southwest), magnetite (central), and mixed sulphidic deposits (north-central) (Marinos 1951). The repeated use of some sites for metal production, attested from their remarkably larger size (e.g. Skouries, Kephala, Phournoi), despite the absence of any clear large ore deposits in their environs, may have been brought about by initial landscape learning needs (Meltzer 2003, 237), possibly maintained through generations with ritual and memory-invoking connotations (Childs and Killick 1993, 328; Gosselain 2010, 196). Different types of furnace are not found mixed on the same site, with the possible exception of Kephala and Avessalos (the latter certainly largely composed also of later material), suggesting that the groups using a particular site maintained, to a large extent, the same technological tradition in furnace shape. Visits to the sources and the metal production sites would have been seasonal and relatively short (Broodbank 2000, 9296). Although the same physical landscape may have been exploited by different groups, the conditions to acquire and adopt elements of new, different technologies, as is attested during longer modern mining rushes (Hardesty 2003), may not have been favourable.

Anthropological enquiry into the transmission of technological knowledge has highlighted the complexities underlying attempts to associate technological practice with social boundaries and social identities as well as the different dynamics pertaining in each stage of the production process (Stark 1998; Gosselain 2000; 2011). Ultimately, this paper only attempted a preliminary discussion, focusing on a single technological trait of only one stage within the metallurgical chaîne opératoire. A fuller analysis, integrating all other evidence for smelting technology (nature of raw materials, slag composition, etc.) is necessary for these questions to be addressed, along with incorporation of other material evidence from these sites, particularly the pottery. It should, however, be noted that slag compositions may show similarities or differences reflecting natural homogeneity or variation in raw materials, with differences in furnace design thus being more suggestive (Iles and Martinón-Torres 2009). Furthermore, smelting technology and spatial distribution need to be understood within the entire production sequence. Still, the present evidence highlights the potential of such an approach in the study of EBA southern Aegean metal production to inform on much more than the technology of the processes alone. Furthermore, the unique landscape of the region, largely composed of islands, combined with the scattered spatial distribution 
of ore sources and production sites, leave no doubt that seasonal mobility was a prerequisite among metal production craftspeople in the EBA southern Aegean.

\section{ACKNOWLEDGMENTS}

I am thankful to E. Kiriatzi and C. Knappett for their invitation to participate in this workshop and volume, which helped me formulate some of the ideas discussed in this paper. I owe special gratitude to Dr Y. Bassiakos for introducing me to Cycladic archaeometallurgy and encouraging my work in this field ever since. An earlier draft of this paper was significantly improved through comments and corrections by E. Kiriatzi and two anonymous reviewers.

\section{BIBLIOGRAPHY}

Bassiakos, Y. and C. Doumas (1998). "The island of Keros and its enigmatic role in the Aegean E.B.A.: A geoarchaeological approach". In Argyritis Gi: Charisterion ston Konstantino I. Conophago. Athens: NTUA Press, pp. 55-64.

Bassiakos, Y. and M. Catapotis (2006). "Reconstruction of the copper smelting process based on the analysis of ore and slag samples", in P. P. Betancourt (ed.), The Chrysokamino Metallurgy Workshop and its Territory. Hesperia Supplement 36. Princeton, New Jersey: American School of Classical Studies at Athens, pp. 329353.

Bassiakos, Y. and O. Philaniotou (2007). "Early copper production on Kythnos: archaeological evidence and analytical approaches to the reconstruction of the metallurgical process". In P.M. Day and R.C.P. Doonan (eds.), Metallurgy in the Early Bronze Age Aegean. Sheffield Studies in Aegean Archaeology 7. Oxford: Oxbow Books, pp. 19-56.

Bassiakos, Y. and Th. Tselios (2012). "On the cessation of local copper production in the Aegean in the $2^{\text {nd }}$ millennium BC", in V. Kassianidou and G. Papasavvas (eds.) Eastern Mediterranean Metallurgy and Metalwork in the Second Millennium BC. A Conference in Honour of James D. Muhly, Nicosia, $10^{\text {th }}-11^{\text {th }}$ October 2009, Oxford: Oxbow Books, pp.151-161.

Betancourt, P. P. ed. (2006a). The Chrysokamino Metallurgy Workshop and its Territory. Hesperia Supplement 36. Princeton, New Jersey: American School of Classical Studies at Athens.

Betancourt, P. P. (2006b). "Discussion of the workshop and reconstruction of the smelting practices". In P. P. Betancourt (ed.), The Chrysokamino Metallurgy Workshop and its Territory. Hesperia Supplement 36. Princeton, New Jersey: American School of Classical Studies at Athens, pp. 179-189.

Betancourt, P. P. (2006c). "Survey conclusions". In P. P. Betancourt (ed.), The Chrysokamino Metallurgy Workshop and its Territory. Hesperia Supplement 36. Princeton, New Jersey: American School of Classical Studies at Athens, pp. 257278.

Brodie, N. and M. Georgakopoulou (2015). "Investigations on Kavos Promontory", in A.C. Renfrew, O. Philaniotou, G. Gavalas, N. Brodie, M. Boyd (eds.), Kavos and the Special Deposits. Cambridge: McDonald Institute for Archaeological Research, pp. 507-520. 
Broodbank, C. (2000). An Island Archaeology of the Early Cyclades. Cambridge: Cambridge University Press.

Caskey, M., L. Mendoni, A. Papastamataki, and N. Beloyannis (1988). "Metals in Keos: a first approach". In P. G. Marinos and G. C. Koukis (eds.), The Engineering Geology of Ancient Works, Monuments and Historical Sites. Proceedings of the Symposium of the International Association of Engineering Geology, Athens. Rotterdam: A.A. Balkema, pp. 1739-1745.

Catapotis, M. (2007). "On the spatial organisation of copper smelting activities in the southern Aegean during the Early Bronze Age". In P.M. Day and R.C.P. Doonan (eds.), Metallurgy in the Early Bronze Age Aegean. Sheffield Studies in Aegean Archaeology 7. Oxford: Oxbow Books, pp. 207-223.

Catapotis, M., O. Pryce, and Y. Bassiakos (2008). "Preliminary results from an experimental study of perforated copper-smelting shaft furnaces from Chrysokamino (Eastern Crete)". In I. Tzachili (ed.), Aegean Metallurgy in the Bronze Age. Proceedings of an International Symposium Held at the University of Crete, Rethymnon, Greece on November 19-21, 2004. Athens: Ta Pragmata Publications, pp. 113-121.

Catapotis, M., Y. Bassiakos, and Y. Papadatos (2011). "Reconstructing early Cretan metallurgy: analytical evidence from Kephala Petras, Siteia”. In P.P. Betancourt and S.C. Ferrence (eds.), Metallurgy: Understanding How, Learning Why. Studies in Honour of James D. Muhly. Philadelphia: INSTAP Academic Press, pp. 69-78.

Childs, S. T. and D. Killick (1993). "Indigenous African metallurgy: nature and culture", Annual Review of Anthropology 22, pp. 317-37.

Cohen, C. R., Th. Rehren, and M. van Buren (2009). "When the wind blows: environmental adaptability in current day silver production within the Bolivian Andes". In J. F. Moreau, R. Auger, J. Chabot, and A. Herzog (eds.), Proceedings of the 36th International Symposium on Archaeometry, 2-6 May 2006, Québec City, Canada. 2006. (Cahiers d'Archéologie du CELAT 25). Quebec: CELAT, Université Laval, pp. 465-475.

Coleman, J. E. (1977). Keos I: Kephala. A Late Neolithic Settlement and Cemetery. Princeton: Princeton University Press.

Conophagos, K. (1980). To Archaio Lavrio kai I Elliniki Techniki Paragogis tou Argyrou. Athens: Ekdotiki Ellados.

Craddock, P.T. (2001). "From hearth to furnace: evidences for the earliest metal smelting technologies in the Eastern Mediterranean", Paléorient 26, pp. 151-65.

Day, P. M. and R.C.P. Doonan (2007). Metallurgy in the Early Bronze Age Aegean. Sheffield Studies in Aegean Archaeology 7. Oxford: Oxbow Books.

Doumas, C. G. (2011). "Searching for the Early Bronze Age Aegean metallurgist's toolkit". In P.P. Betancourt and S.C. Ferrence (eds.), Metallurgy: Understanding How, Learning Why. Studies in Honour of James D. Muhly. Philadelphia: INSTAP Academic Press, pp. 165-179.

Gale, N. H. and Z. A. Stos-Gale (1981). "Cycladic lead and silver metallurgy", The Annual of the British School at Athens 76, pp. 169-224.

Gale, N. H. and Z.A. Stos-Gale (2002). "Archaeometallurgical research in the Aegean". In M. Bartelheim, E. Pernicka, R. Krause (eds.), The Beginnings of Metallurgy in the Old World. Forschungen zur Archäometrie und Altertumswissenschaft 1. Rahden/Westf.: Verlag Marie Leidorf, pp. 277-302. 
Gale, N. H. and Z. A. Stos-Gale (2008). "Changing patterns in prehistoric Cycladic metallurgy". In N. Brodie, J. Doole, G. Gavalas, and C. Renfrew (eds.), Horizon: A Colloquium on the Prehistory of the Cyclades. McDonald Institute Monographs. Cambridge/Athens Greece: McDonald Institute for Archaeological Research/Stavros Niarchos Foundation, pp. 387-408.

Gale, N. H., A. Papastamataki, Z. A. Stos-Gale, and K. Leonis (1985). "Copper sources and copper metallurgy in the Aegean Bronze Age". In P. T. Craddock and M. J. Hughes (eds.), Furnaces and Smelting Technology in Antiquity. British Museum Occasional Paper No. 48. London: British Museum, pp. 81-101.

Gale, N. H., M. Kayafa, and Z.A. Stos-Gale (2008). "Early Helladic metallurgy at Raphina, Attica, and the role of Lavrion”. In I. Tzachili (ed.), Aegean Metallurgy in the Bronze Age. Athens: Proceedings of an International Symposium Held at the University of Crete, Rethymnon, Greece on November 19-21, 2004. Athens: Ta Pragmata Publications, pp. 87-104.

Gauss, W. (2010). “Aegina Kolonna”. In E. H. Cline (ed.), The Oxford Handbook of the Bronze Age Aegean (ca. 3000-1000BC). Oxford: Oxford University Press, pp. 738-751.

Georgakopoulou, M. (2007a). "The metallurgical remains". In A. C. Renfrew, C. Doumas, L. Marangou, and G. Gavalas (eds.), Keros, Dhaskalio Kavos: The Investigations of 1987-88. McDonald Institute Monographs. Cambridge: McDonald Institute for Archaeological Research, University of Cambridge, pp. 380-401.

Georgakopoulou, M. (2007b). "Metallurgical activities within Early Cycladic settlements: the case of Daskalio-Kavos". In P. M. Day and R. C. P. Doonan (eds.), Metallurgy in the Early Bronze Age Aegean. Sheffield Studies in Aegean Archaeology 7. Oxford: Oxbow Books, pp. 123-134.

Georgakopoulou, M. (2013). "Metal artefacts and metallurgy", in A.C. Renfrew, O. Philaniotou, G. Gavalas, N. Brodie, M. Boyd (eds.), The Sanctuary on Keros and the Origins of Aegean Ritual Practice: the Excavations of 2006-2008. Volume I: The Settlement at Dhaskalio. Cambridge: McDonald Institute, pp. 667-692.

Georgakopoulou, M. (in press a). "Lead isotope analysis and metal production models for the Bronze Age Aegean". In Y. Bassiakos (ed.), Prehistoric Metal Production in the Aegean: Material Evidence and Analysis. Heidelberg. Springer Verlag.

Georgakopoulou, M. (in press b). "Metal and Metallurgical remains". In C. Renfrew, M. Marthari, K. Dellaporta, M. J. Boyd, N. J. Brodie, G. Gavalas, J. Hilditch, and J. Wright (eds.), The Keros Island Survey. Cambridge: McDonald Institute for Archaeological Research.

Georgakopoulou, M. (in press c), "Metal production, working and consumption across the sites at Dhaskalio and Kavos". In A.C. Renfrew, O. Philaniotou, G. Gavalas, N. Brodie, M. Boyd (eds.), The Sanctuary on Keros and the Origins of Aegean Ritual Practice: the excavations of 2006-2008, Vol. III: The Marble Finds from Kavos and the Archaeology of Ritual. Cambridge: McDonald Institute for Archaeological Research.

Georgakopoulou, M., Y. Bassiakos, and O. Philaniotou (2011). "Seriphos surfaces: a study of copper slag heaps and copper sources in the context of Early Bronze Age Aegean metal production", Archaeometry 53, pp. 123-145.

Georgiadis, M. (2008). "The obsidian in the Aegean beyond Melos: an outlook from Yali”, Oxford Journal of Archaeology 27, pp. 101-117 
Gosselain, O. P. (2000). "Materialising identities: an African perspective", Journal of Archaeological Method and Theory 7, pp. 187-217.

Gossselain, O. P. (2010). "Exploring the dynamics of African pottery cultures". In R. Barndon, A. Engevik, and I. Øye (eds.), The Archaeology of Regional Technologies: Case Studies from the Palaeolithic to the Age of the Vikings. Lewiston: Edwin Mellen Press, pp. 193-224.

Gosselain, O. P. (2011). "Fine if I do, fine if I don't. Dynamics of technical knowledge in sub-Saharan Africa," in B. W. Roberts and M. V. Linden (eds.), Investigating Archaeological Cultures: Material Culture, Variability and Transmission. New York: Springer Science+Business Media, pp. 211-227.

Hadjianastasiou, O. (1998). "Notes from Kythnos". In L. G. Mendoni and A. J. Mazarakis Ainian (eds.), Kea-Kythnos: History and Archaeology. Proceedings of International Symposium, 22-25 June 1994. Meletemata 27. Athens: KERA-EIE, pp. 259-273. (in Greek)

Hadjianastasiou, O. and S. MacGillivray (1988). "An Early Bronze Age smelting site on the Aegean island of Kythnos; Part Two: The archaeological evidence". In J. E. Jones (ed.), Aspects of Ancient Mining and Metallurgy. Acts of a British School at Athens Centenary Conference at Bangor, 1986. Final Programme and Abstracts of Lectures and Communications Papers. Bangor: Department of Classics, University College of North Wales, pp. 31-4.

Haggis, D. C. (2006). "Chrysokamino in context: a regional archaeological survey". In P. P. Betancourt, The Chrysokamino Metallurgy Workshop and its Territory. Hesperia Supplement 36. Princeton New Jersey: American School of Classical Studies at Athens, pp. 221-232

Hardesty, D.L. (2003). "Mining rushes and landscape learning in the modern world". In M. Rockman and J. Steele (eds.), Colonization of Unfamiliar Landscapes: The Archaeology of Adaptation. London and New York: Routledge, pp. 81-95

Iles, L., Martinón-Torres, M. (2009). "Pastoralist iron production on the Laikipia Plateau, Kenya: wider implications for archaeometallurgical studies", Journal of Archaeological Science 36, pp. 2314-2326.

Kakavogianni, O., K. Douni, F. Nezeri, M. Georgakopoulou, Y. Bassiakos (2006). "Attempted technological approach to silver and lead production during the Final Neolithic and Early Helladic I in Mesogeia". In Ancient Greek Technology: Proceeings of the 2nd International Conference on Ancient Greek Technology. Athens: Technical Chamber of Greece, pp. 77-83 (in Greek).

Kakavogianni, O., K. Douni, and F. Nezeri (2008). "Silver metallurgical finds dating from the end of the Final Neolithic period until the Middle Bronze Age in the area of Mesogeia". In I. Tzachili (ed.), Aegean Metallurgy in the Bronze Age. Proceedings of an International Symposium Held at the University of Crete, Rethymnon, Greece on November 19-21, 2004. Athens: Ta Pragmata Publications, pp. 45-57.

Kakavogiannis, E. (2005). Metalla ergasima kai sygkexoremena: The Organisation of Lavreotiki Mineral Resource Exploitation by the Athenian Democracy A $\theta$ ñ $\alpha$. Archaeiologikon Deltion Publications 90. Athens: Ministry of Culture Archaeological Receipts Fund (in Greek).

Kayafa, M., Z. A. Stos-Gale, and N. H. Gale (2000). "The circulation of copper in the Early Bronze Age in Mainland Greece: the lead isotope evidence from Lerna, Lithares and Tsoungiza”. In C. F. E. Pare (ed.), Metals Make the World Go Round. The Supply and Circulation of Metals in Bronze Age Europe. Proceedings 
of a Conference Held at the University of Birmingham in June 1997. Oxford: Oxbow Books, pp. 39-55.

Kiriatzi, E. (2003). "Sherds, fabrics and clay sources: reconstructing the ceramic landscapes of prehistoric Kythera," in K.P. Foster and R. Laffineur (eds.), METRON: Measuring the Aegean Bronze Age-Proceedings of the $9^{\text {th }}$ International Aegean Conference, New Haven, Yale University, 18-21 April 2002. Aegaeum 24. Liège and Austin: Université de Liège, Histoire de l'art et archéologie de la Grèce antique and University of Texas at Austin, Program in Aegean Scripts and Prehistory, pp. 123-130.

Kiriatzi, E., M. Georgakopoulou, and A. Pentedeka (2011). "Pottery production and importation at Bronze Age Kolonna: the ceramic fabrics and the island's landscape". In W. Gauss and E. Kiriatzi, Pottery Production and Supply at Bronze Age Kolonna, Aegina: an Integrated Archaeological and Scientific Study of a Ceramic Landscape. Contributions to the Chronology of the Eastern Mediterranean 7 Ägina - Kolonna. Forschungen und Ergebnisse 5 Vienna: Austrian Academy of Sciences Press, pp. 69-156.

Marinos, G. (1951). "Geologia kai Metallogenesi tis Nisou Serifou”, Geologikai kai Geophysikai Meletai. Athens: IGME Publications, pp. 95-127 (in Greek).

Meltzer, D. J. (2003). "Lessons in landscape learning”. In M. Rockman and J. Steele (eds.), Colonization of Unfamiliar Landscapes: The Archaeology of Adaptation. London and New York: Routledge, pp. 222-241.

Mountjoy, P. A. (1995). "Thorikos Mine No.3: The Mycenean pottery", The Annual of the British School at Athens 90, pp. 195-227.

Muhly, J. D. (2004). "Chrysokamino and the beginnings of metal technology on Crete and in the Aegean," in L. P. Day, M. S. Mook, and J. D. Muhly (eds.), Crete Beyond the Palaces. Proceedings of the Crete 2000 Conference. Philadelphia: INSTAP Academic Press, pp. 283-9.

Ottaway, B. S. (2001). "Innovation, production and specialization in early prehistoric copper metallurgy", European Journal of Archaeology 4, pp. 87-112.

Pantou, P. (in press). "Evidence of prehistoric habitation and metallurgical activities on Seriphos: the site of Plakalona". In Y. Bassiakos (ed.), Prehistoric Metal Production in the Aegean: Material Evidence and Analysis. Heidelberg: Springer Verlag.

Papadatos, Y. (2007). "The beginning of metallurgy in Crete: new evidence from the FN-EMI settlement at Kephala Petras, Siteia”. In P.M. Day and R.C.P. Doonan (eds.), Metallurgy in the Early Bronze Age Aegean. Sheffield Studies in Aegean Archaeology 7. Oxford: Oxbow Books, pp. 154-167.

Papadopoulou, Z. D. (2011). "Akrotiraki and Skali: new evidence for EBA lead/ silver and copper production from southern Siphnos". In P.P. Betancourt and S.C. Ferrence (eds.), Metallurgy: Understanding How, Learning Why. Studies in honor of James D. Muhly. Prehistory Monographs 29. Philadelphia: INSTAP Academic Press, pp. 149-156.

Papadopoulou, Z. (2013). "Archaeometallurgical research in southern Siphnos: finds, questions, perspectives". In G. Zervoudakis (ed.), Proceedings of the $4^{\text {th }}$ Siphnian Symposium, Siphnos 25-26 June 2010. Athens: Society for Sifnean Studies, pp. 29-44 (in Greek).

Pelton, A., M. G. Stamatakis, E. Kelepertzis, T. Panagou (2015). "The origin and archaeometallurgy of a mixed sulphide ore for copper production on the island of Kea, Aegean Sea, Greece”, Archaeometry 57, pp. 318-343. 
Philaniotou, O., Y. Bassiakos, and M. Georgakopoulou (2011). "Early Bronze Age copper production on Seriphos (Cyclades, Greece)". In P.P. Betancourt and S.C. Ferrence (eds.), Metallurgy: Understanding How, Learning Why. Studies in Honour of James D. Muhly. Prehistory Monographs 29. Philadelphia: INSTAP Academic Press, pp. 157-164

Pryce, T. O., Y. Bassiakos, M. Catapotis, R. C. Doonan (2007). “'De Caerimoniae' technological choices in copper-smelting furnace design at Early Bronze Age Chrysokamino, Crete", Archaeometry 49, pp. 543-557.

Pryce, T. O., V. C. Pigott, M. Martinón-Torres, and Th. Rehren (2010). "Prehistoric copper production and technological reproduction in the Khao Wong Prachan Valley of Central Thailand", Archaeological and Anthropological Sciences 2, pp. 237-264.

Renfrew, C., M. Boyd, C. B. Ramsey (2012). "The oldest maritime sanctuary? Dating the sanctuary at Keros and the Cycladic Early Bronze Age", Antiquity 86, pp. 144-160.

Spitaels, P. (1984). "The Early Helladic Period in Mine No. 3". In H. F. Mussche, J.Bingen, J. Servais, and P. Spitaels (eds.), Thorikos VIII 1972/1976. Gent: Comité des Fouilles Belges en Grèce, pp. 151-174.

Stark, M. T. ed. (1998). The Archaeology of Social Boundaries. Washington D.C.: Smithsonian Institution Press.

Stos-Gale, Z. A. (1989). "Cycladic copper metallurgy". In A. Hauptmann, E. Pernicka, and G. A. Wagner (eds.), Old World Archaeometallurgy. Proceedings of the International Symposium 'Old World Archaeometallurgy', Heidelberg 1987. Der Anschnitt, Beiheft 7. Bochum: Deutsches Bergbau-Museum, pp. 279-291.

Stos-Gale, Z. A. (1998). "The role of Kythnos and other Cycladic islands in the origins of Early Minoan metallurgy". In L. G. Mendoni and A. J. Mazarakis Ainian (eds.), Kea-Kythnos: History and Archaeology. Proceedings of International Symposium, 22-25 June 1994. Meletemata 27. Athens/Paris: KERAEIE/Diffusion de Boccard, pp. 717-735.

Stos-Gale, Z. A. (2000). "An overview of lead isotope data for provenance studies and the trade in metals in the Bronze Age Mediterranean". In C. F. E. Pare (ed.), Metals Make the World Go Round: The Supply and Circulation of Metals in Bronze Age Europe. Oxford: Oxbow Books, pp. 56-69.

Stos-Gale, Z. A. and N. H. Gale (2003). "Lead isotopic and other isotopic research in the Aegean". In K. P. Foster and R. Laffineur (eds.), METRON: Measuring the Aegean Bronze Age-Proceedings of the $9^{\text {th }}$ International Aegean Conference, New Haven, Yale University, 18-21 April 2002. Aegaeum 24. Liège and Austin: Université de Liège, Histoire de l'art et archéologie de la Grèce antique and University of Texas at Austin, Program in Aegean Scripts and Prehistory, pp. 83101.

Stos, Z. and N. Gale (2006). "Lead isotope and chemical analyses of slags from Chrysokamino". In P. P. Betancourt (ed.), The Chrysokamino Metallurgy Workshop and its Territory. Hesperia Supplement 36. Princeton New Jersey: American School of Classical Studies at Athens, pp. 299-319.

Theocharis, D.M. (1951). "Excavation at Arafina", Proceedings of the Athens Archaeological Society, pp. 77-92. (in Greek)

Theocharis, D.M. (1952). "Excavation at Arafina", Proceedings of the Athens Archaeological Society, pp. 129-151. (in Greek) 
Wagner, G. A. and G. Weisgerber (1985). Silber, Blei und Gold auf Sifnos. Prähistorische und Antike Metallproduktion. Der Anschnitt, Beiheft 3. Bochum: Veröffentlichungen aus dem Deutschen Bergbau-Museum, Nr. 31.

Walter, H. and F. Felten (1981). Alt-Ägina III.1. Die vorgeschichtilche Stadt: Befestigungen. Haüser Funde. Mainz am Rhein: Verlag Philipp von Zabern.

Weisgerber, G. (2003). "Spatial organisation of mining and smelting in Feinan, Jordan: mining archaeology beyond the history of technology". In P. T. Craddock and J. Lang (eds.), Mining and Metal Production Through the Ages. London: British Museum Press, pp. 76-89.

Wilson, D. E. (1999). Keos IX. Ayia Irini: Periods I-III. The Neolithic and Early Bronze Age Settlements, pt 1: The pottery and small finds. Keos results of excavations conducted by the University of Cincinnati under the auspices of the American School of Classical Studies at Athens 9:1.Mainz am Rhein: Verlag Philipp von Zabern.

Zacharias, N., C. T. Michael, O. Philaniotou-Hadjianastasiou, A. Hein, and Y. Bassiakos (2006a). "Fine-grain TL dating of archaeometallurgical furnace walls", Journal of Cultural Heritage 7, pp. 23-29.

Zacharias, N., C. T. Michael, M. Georgakopoulou, V. Kilikoglou, and Y. Bassiakos (2006b). "Quartz TL Dating on Selected Layers from Archaeometallurgical Kiln Fragments: a Proposed Procedure to Overcome Age Dispersion", Geochronometria 25, 29-35.

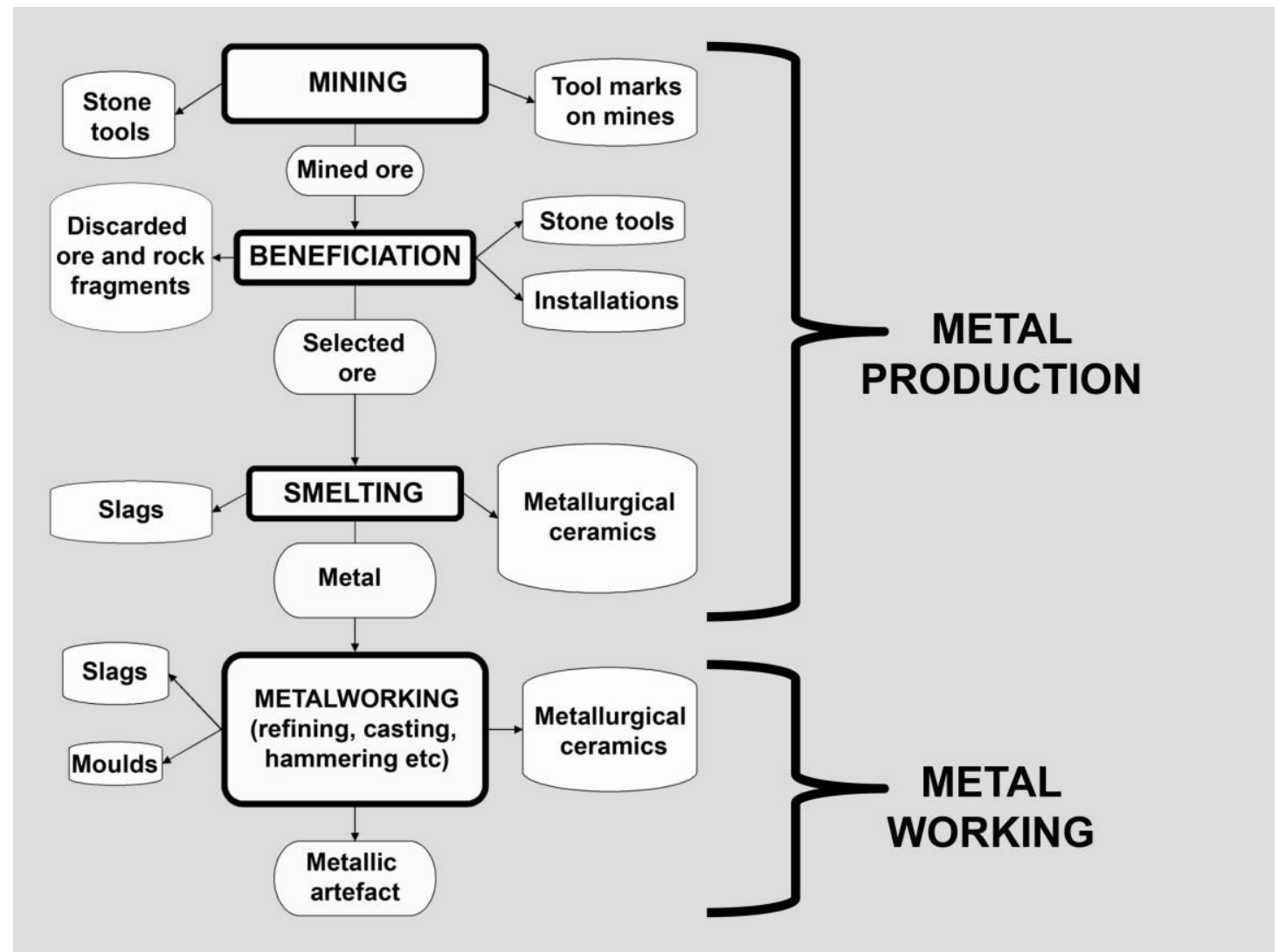

Figure 4.1 Simplified diagram showing basic steps involved in the production of metals 


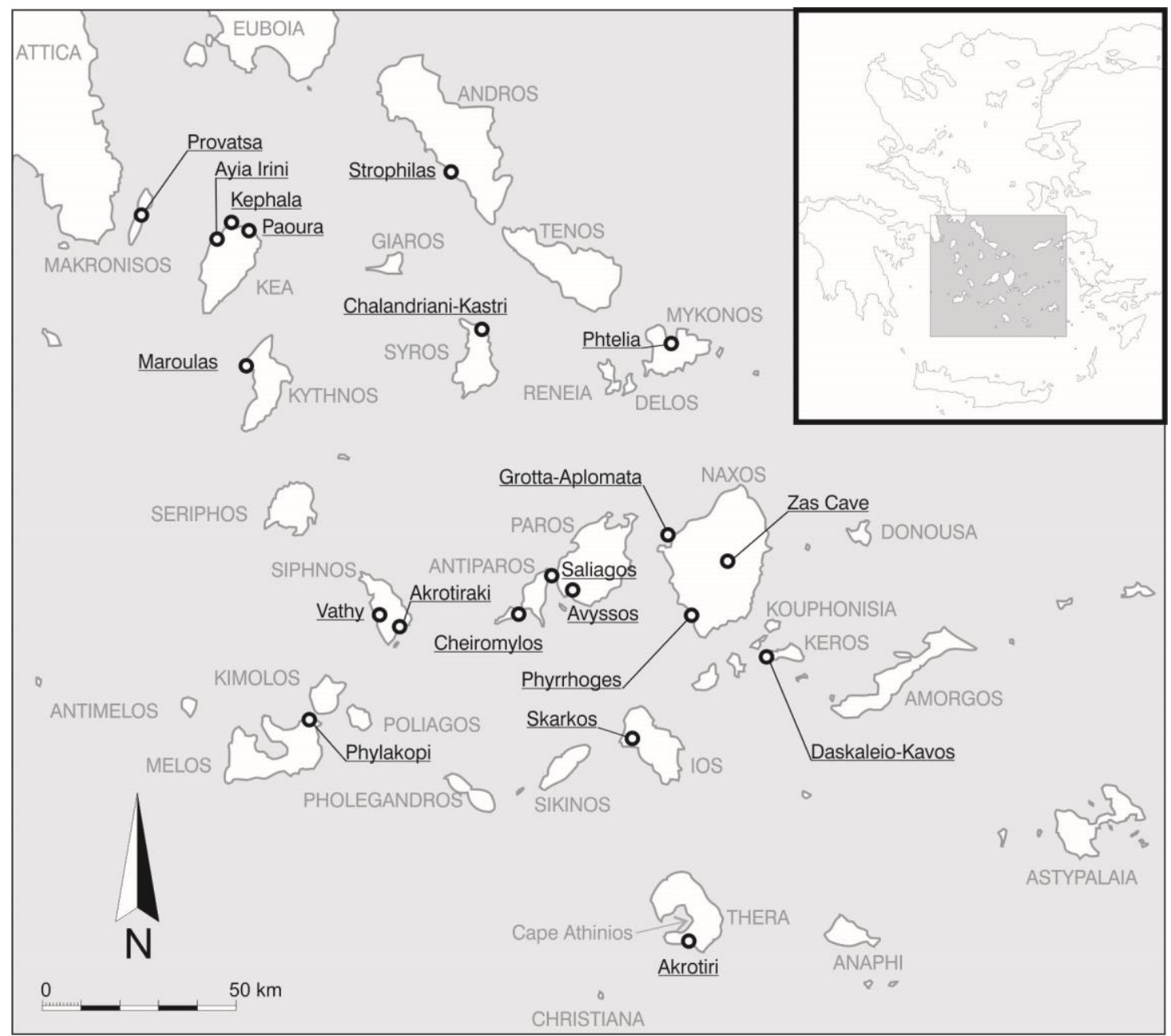

Figure 4.2 Map of the Cyclades and southeast Attica showing location of smelting sites discussed in the text. In the smaller Aegean map are depicted the locations of Chrysokamino (1) and Kephala Petras (2) on Crete. The scale of the map does not allow separate representation of the copper smelting site of Skali and the lead smelting site of Kasela on Siphnos, both are represented by the immediately adjacent Akrotiraki settlement. 


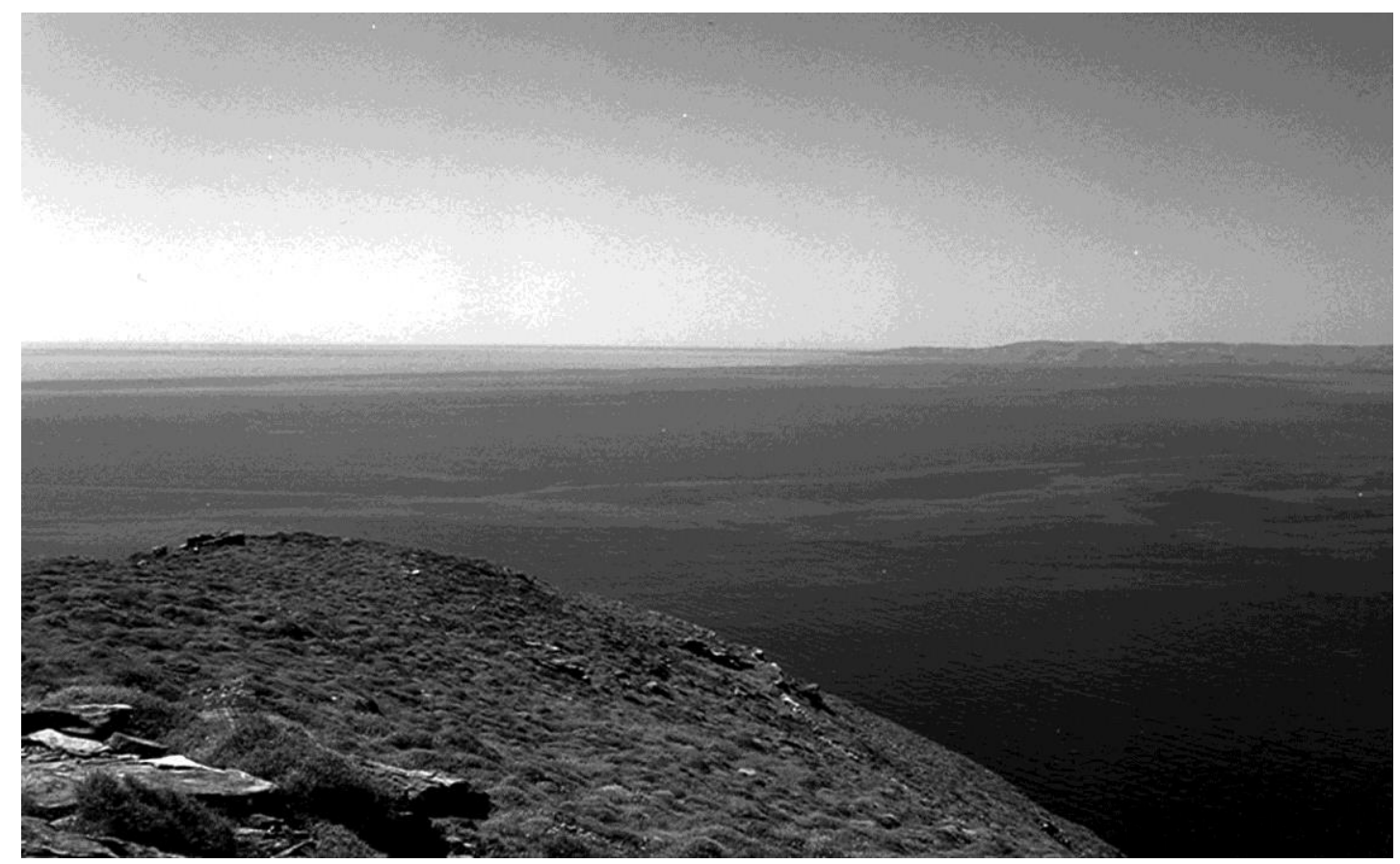

Figure 4.3 View of Kythnos from the Kephala (Seriphos) slag heap (distance c. 14km)

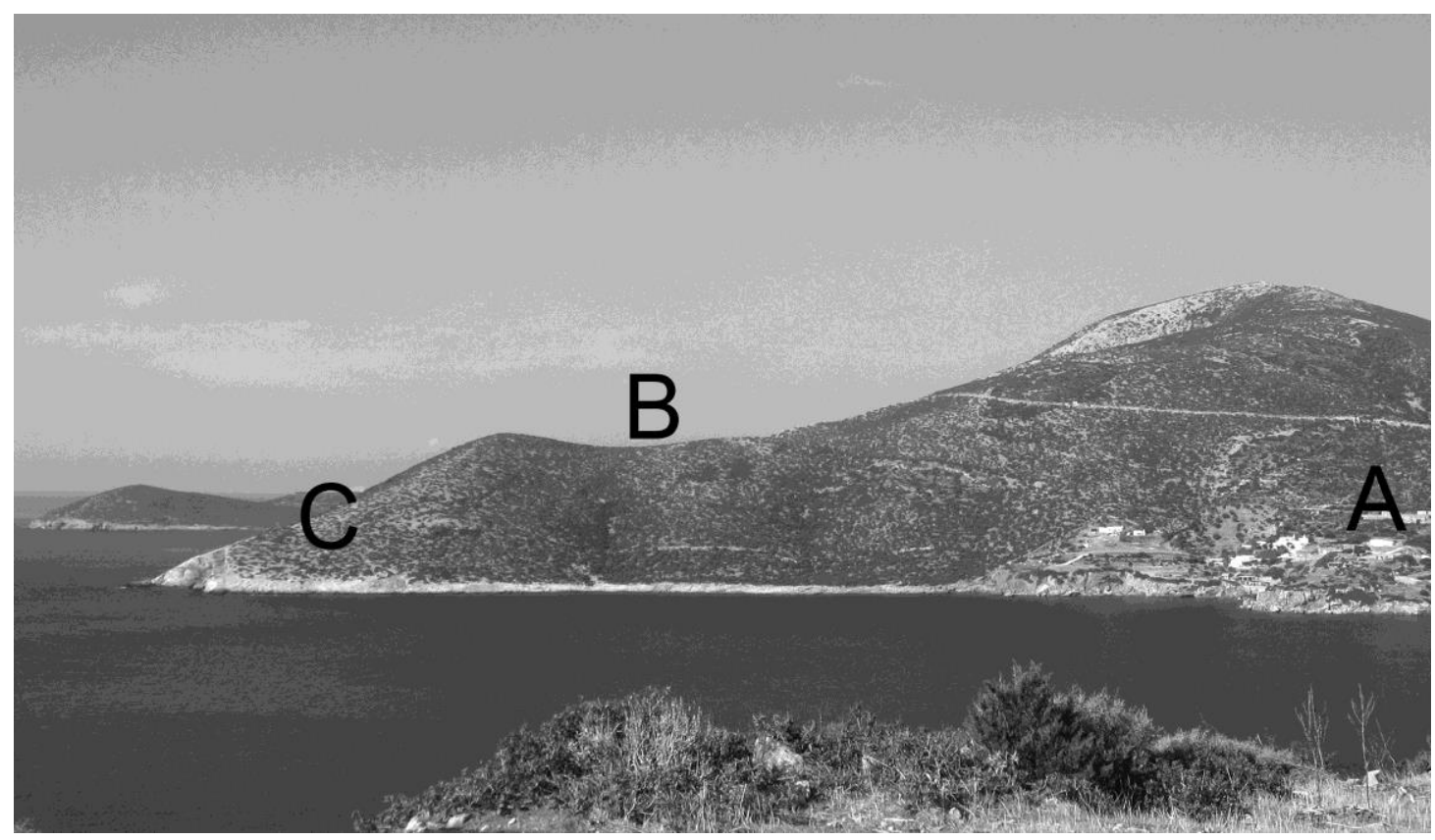

Figure 4.4 View of Akrotiraki (A), Skali (B), and Kasela (C) from opposite coast of Platy Gialos bay (Siphnos) 


\begin{tabular}{|c|c|c|c|c|c|}
\hline REGION & SITE & METAL & DATE & $\begin{array}{l}\text { SPATIAL } \\
\text { PATTERN }\end{array}$ & \begin{tabular}{|c} 
PRESENCE OF \\
PERFORATED \\
FURNACE FRAGS \\
\end{tabular} \\
\hline Attica & Raphina & Copper & EBII & $\mathrm{C}$ & Y? \\
\hline Kea & Kephala & Copper & FN & $\mathrm{C}$ & Y? \\
\hline \multirow[t]{5}{*}{ Kythnos } & Skouries & Copper & EBII only? & $\mathrm{A}$ & \\
\hline & Pounta & Copper & EBA & $\mathrm{B}$ & \\
\hline & $\begin{array}{l}\text { Paliopyrgos- } \\
\text { Aspra Spitia }\end{array}$ & Copper & EBA & B & $\mathrm{Y}$ \\
\hline & Sideri & Copper & $\begin{array}{l}\text { EBA (and } \\
\text { early MBA?) }\end{array}$ & B & $\mathrm{Y}$ \\
\hline & Lefkes & Copper & EBA & $\mathrm{C} ?$ & \\
\hline \multirow[t]{3}{*}{ Seriphos } & Avessalos & Copper & EBA and later & $\mathrm{A}$ & $\mathrm{Y}$ \\
\hline & Kephala & Copper & EBA & $\mathrm{A}$ & $\mathrm{Y}$ \\
\hline & Phournoi & Copper & EBA & A & \\
\hline \multirow[t]{3}{*}{ Siphnos } & A. Sostis & Lead & EBA & $\mathrm{A}$ & \\
\hline & Skali & Copper & EBA & $\mathrm{C}$ & \\
\hline & Kasela & Lead & EBA & $\mathrm{C}$ & $\mathrm{Y}$ \\
\hline Keros & $\begin{array}{l}\text { Dhaskalio- } \\
\text { Kavos }\end{array}$ & Copper & EBII-III & $\mathrm{D}$ & \\
\hline \multirow[t]{2}{*}{ Crete } & Chrysokamino & Copper & $\begin{array}{l}\text { FN- } \\
\text { EMIII(mainly } \\
\text { EMIII?) }\end{array}$ & $\mathrm{D}$ & $\mathrm{Y}$ \\
\hline & $\begin{array}{l}\text { Kephala- } \\
\text { Petras }\end{array}$ & Copper & FN-EMI & $\mathrm{D}$ & \\
\hline
\end{tabular}

TABLE 1. Main smelting sites discussed in the text. Spatial patterns are grouped as follows (A: Large scale, in the 'metal-rich' area, in isolation from settlements; B: Smallscale, in the 'metal-rich' area, in isolation from settlements; C: Small-scale, in the 'metal-rich' area, in the vicinity of a settlement; D: Small/ medium-scale away from ore sources, in the vicinity of a settlement; FN: Final Neolithic; EBA: Early Bronze Age; EM: Early Minoan) 


\begin{tabular}{|c|c|c|c|c|c|}
\hline SITE & DATE & $\begin{array}{c}\text { SMELTE } \\
\text { D } \\
\text { METAL }\end{array}$ & $\begin{array}{c}\text { THICKNESS } \\
\text { OF WALLS } \\
\text { (CM) }\end{array}$ & $\begin{array}{c}\text { DIRECTION OF } \\
\text { HOLES ON } \\
\text { FURNACE } \\
\text { FRAGMENTS } \\
\end{array}$ & $\begin{array}{c}\text { FREQUENCY OF } \\
\text { PERFORATED } \\
\text { FURNACE } \\
\text { FRAGS } \\
\end{array}$ \\
\hline Kephala (Kea) & FN & Copper & $?$ & $?$ & $?$ \\
\hline Raphina (Attica) & EBII & Copper & $?$ & $?$ & $?$ \\
\hline $\begin{array}{l}\text { Paliopyrgos } \\
\text { (Kythnos) }\end{array}$ & EBA & Copper & c. 4 & $\begin{array}{l}\text { At an angle } \\
\text { downwards }\end{array}$ & All \\
\hline Sideri (Kythnos) & $\begin{array}{l}\text { EBA (and } \\
\text { early } \\
\text { MBA?) }\end{array}$ & Copper & c. 4 & $\begin{array}{l}\text { At an angle } \\
\text { downwards }\end{array}$ & All \\
\hline $\begin{array}{l}\text { Kephala } \\
\text { (Seriphos) }\end{array}$ & EBA & Copper & c. 4 & $\begin{array}{l}\text { At an angle } \\
\text { downwards }\end{array}$ & Very few \\
\hline $\begin{array}{l}\text { Avessalos } \\
\text { (Seriphos) }\end{array}$ & $\begin{array}{l}\text { EBA } \\
\text { (+later) }\end{array}$ & Copper & c. 4 & $\begin{array}{l}\text { At an angle } \\
\text { downwards }\end{array}$ & Very few \\
\hline $\begin{array}{l}\text { Chrysokamino } \\
\text { (Crete) }\end{array}$ & $\begin{array}{l}\text { EMIII } \\
\text { (+earlier?) }\end{array}$ & Copper & $1-1.5$ & No slope & All \\
\hline $\begin{array}{l}\text { Akrotiraki } \\
\text { (Siphnos) }\end{array}$ & EBII & Lead & c. 4 & $\begin{array}{l}\text { At an angle } \\
\text { downwards }\end{array}$ & All \\
\hline
\end{tabular}

TABLE 2. Sites with perforated furnace fragments in the southern Aegean 